\title{
Searching for the Way in Life: Yang Zhu's Theory of Tending Life in Liezi
}

\author{
--Nan Zhang \\ Assistant Professor, School of Marxism, \\ China Youth University of Political Studies, \\ Beijing, China. \\ Email: zhangnanbrian@ruc.edu.cn
}

https://doi.org/10.3126/litstud.v34i01.39535

\begin{abstract}
Known as a Taoist, Yang Zhuw lived in the Warring States Period. In his only transmitted work named 'Yangzhu'in Liezi, he presented the "tending life" theory which was considered by most scholars as a sort of "hedonism," "extreme egoism" or "indulgence." However, the "tending life" theory should not be simply regarded as an avocation of physical enjoyment. First, 'Yangzhu' defined Tao (the Way) as a "weak power" which only assists things to "auto-generate" and "self-transform," so that "tending life" is also a pursuit of the ultimate meaning of Tao. 'Yangzhu' further argued that the best way of "tending life" is not to restraint and suppress one's natural desire, for the realization of "tending life" should be based on the preservation of the body. 'Yangzhu' discusses the relationship between the "Ming"(name/reputation) and the "Shi"(Reality), which reveal that the attachment to the "reputation" is the main obstacle of the realization of "tending life." At last, Yang Zhu proposed that the most ideal life should "roaming as the nature prompt" through a dialectical discussion. Therefore, the theory of "tending life" also reflects a pursuit that to some extent transcends the physical life.
\end{abstract}

Keywords:Yangzhu, Liezi, tending life, auto-generation, self-transformation

\section{Historical and Textual Issues}

Yang Zhu 楊朱was a person that really existed in history around the middle of the Warring States period, and we can still find this name frequently in those well-known preQin classics such asMenius孟子, Zhuangzi莊子and Hanfeizi韓非子. In those books, he was sometimes called Yang Zi楊子/揚子, Yang Ziju陽子居, Yang Sheng陽生(Qian 186), and was also called “Yang Mo"楊墨together with Mohist. Yang Zhu is generally regarded as one of the representatives of the Taoist school. According to Zhuangzi, Yang Zhu was one of Lao Zi's students. Xu Dishan elaborates this idea in his book ZhongguoDaojiao 
Shi道教史 (The History of Taoism) that the Taoist school spit after Lao Zi into two factions: one represented by Guan Yin關尹 and Lie Zi列子, and the other represented by Yang Zhu(34-35). However, some scholars regard Yang Zhu as a pioneer of the Taoist school (Feng 186). There are also many records about Yang Zhu's thoughts in the pre-Qin literature. For instance, Menciussays that"Yangzi chose egoism. If by pulling out a single hair from his own body he could have benefited the entire world, he would not have done it" (Mencius 150).Besides,Huainanzi淮南子says, "keeping your nature intact, protecting your authenticity, not allowing things to entangle your form: These were established by Yangzi"(A.Liu 1229). Yet the briefestappraise was given by the LüshiChunqiu呂氏春秋,“Yang Zhu, the self”(Lü 433).Although these records were derived from different schools, the descriptions were basically the same, which proves that the main idea of Yang Zhu had already been very clear and well-knownat that time.

However, there is only one work left by Yangzhu today that is chapter 'Yangzhu' in the book Liezi. Ever since Liu Zongyuan's (柳宗元, 773-819) article'Bianliezi 辨列子(66), the disputes of the authenticity of the book Liezi have never stopped, which has become a famous academic case in Chinese intellectual history. In addition, the controversy over the relationship between Yang Zhu and the 'Yangzhu'as well as the 'Yangzhu' and the Lieziremains unresolved. In fact, the question of the relationship between Lieziand 'Yangzhu' has been raised in Han Dynasty by Liu Xiang劉向（77 B.C.- 6 B.C.) in his book Xülu敘錄(The Catalogue).Hefound that “the 'Liming' 力命chapter emphasized the natural position and the uncontrolled fate of man, while the 'Yangzhu' chapter advocated freedom and leisure"(Yang 291).Since the main ideas of the two chapters are so different, Liususpects thatthey were not written by one person.Subsequently, Zhang Zhan張湛(373-396), thegreat annotator of Liezi, also echoed Liu's suspect in his notes. In addition, contemporary scholars also tend to regard the 'Yangzhu' as an independent part describing the thought of the Yang Zhu School. Since it was the only one of the eight articles in Liezi that specifically recorded one's words and actions, Hu Shi胡適(1938-42)argues that "Maybe there used to be such a book named Yangzhu, but the editor casually put it into Liezi in order to made it up to eight chapters"(Hu 150).Besides, Graham(1919-1991) believes that "The 'Yang Chu' chapter is so unlike the rest of the Lieh-tzu that it must be the work of another hand, although probably of the same period (3rd or 4th century A.D.)"(Graham 135). In this way, it is still 
doubtful whether the 'Yangzhu' was a pre-Qin text. Some scholars believe that the it reflected the thoughts in the Wei and Jin Dynasties, because the indulgent incline in it was apparently contradicted to Yang Zhu'stheory of "tending life(養生)"1. We also cannot ignore the obvious difference between the 'Yangzhu' and the thoughts in Wei and Jin Dynasties. ${ }^{2}$ That is why others oppositely argued that the 'Yangzhu' was indeed a work of the Yang Zhu School in the middle and late Warring States Period. It can be seen that the scholars now have not yet reached anagreement on the various questions about 'Yangzhu' text.

Though theauthenticity ofLieziis not my research'sfocus, it's still necessary to make a simple explanation about it.The relationship between the 'Yangzhu' and the Liezi may be a pre-understanding of the argumentsin this article. In fact, such documentary issues werevery common in ancient Chinese books.For instance, the article 'Lieyukou'列禦完, which was mainly related to Lie $\mathrm{Zi}$, was also one of chapters inZhuangzi. We should note that most of ancient books were finally edited during the Han Dynasty, and what those editors did was to compile deferentchapters into one book. This kind of compilation was unlikely irrational, because they usually tend to incorporate texts from the same school into a book. It cannot be denied that there are subtle differences in thoughts between the different branches of a school. However, in a sense, those differences are more like deferentaspects of the same view. This may be the main reason why the 'Lieyukou' was put into the Zhuangzi and the 'Yangzhu' was one of chapters inLiezi. Therefore, we believe that the 'Yang Zhu' chapter was not completely independent from the Liezi, but an integral part of it. Only in this way could we approach the core of the "tending life" theory proposed by the 'Yangzhu' and explore the same spirit behind the seemingly contradictory thoughts.

\section{Auto-Generation and Self-Transformation: The Theoretical Basis of "Tending Life"}

"Tending life" is one of the main issues discussed in 'Yangzhu', which was a common concern of the Pre-Qin Taoist scholars. For example, Laozi $i$ 老子 remarks that:

Chapter.03 They empty the hearts-and-minds of the people and fill their stomachs. They weaken their aspirations and strengthen their bones (mes, R. T, \& Hall, D. L. 179).

Chapter.13 Thus those who value the care of their own persons more than running the world can be entrusted with the world (199).

Chapter.44 Your reputation or your person-which is dearer to you? 
Your person or your property — which is worth more? (284)

It advocated that the conservation of the physical life should be conformed to the natural state instead of being over-protected. Zhuangzi also proposed a similar proposition. There is a chapter in the Zhuangzinamed Yangshengzhu養生主, which emphasized that thePrimacy of life is the "spirit," and nourishing Life should focus on the transcendence of the inner soul rather than the maintenance of the physical body. Besides, in the 'Renjianshi'人間世, there was a saying noted "With a crippled body, he's still able to look after himself and finish out the years Heaven gave him. How much better, then, if he had crippled virtue"(Watson 123), which to an extent showed the focus of the relationship between physical and spiritual life in the Taoist tradition.

Theories of cosmogenesis proposed by the Laozi and the Zhuangzi were more likely to be a sort of "co-generation" theory or aformthatwasquite similar to the creationism(Cao, “Auto-Generation," 18-26). In otherwords, Tao(道, the Way) is the ultimate source and the highest entity of all things in the world, and is transcendent throughout the universe. It can be said that everything in the universe is actually a separation of Tao. In addition, there's no other creature but people could perceive and pursue Tao that has been already inherent in them. In this context, people's physical lives are not only the basis of survival, but also the carrier of Tao to reveal it as well as the intermediary of people to pursue the ultimate meaning. Therefore, the thought of "tending life" in the Laozi and the Zhuangzi actually had the meaning that people should overcome the limitations of their physical bodies and regard the realization of the Tao as the ultimate goal of their lives.

As aTaoistbook, Lieziregards Tao as the ultimate meaning of people's life, but the theory of Tao and "tending life" in Liezi are quitedifferent from that of Laozi and Zhuangzi. At the beginning ofLiezi, the cosmological idea of "auto-generation and selftransformation" has been put forward. In the chapter 'Tianrui' 天瑞, we can see:

There are the born and the Unborn, the changing and the Unchanging. The Unborn can give birth to the born; the Unchanging can change the changing. The born cannot escape birth, the hanging cannot escape change; therefore, birth and change are the norm. Things for which birth and change are the norm are at all times being born and changing. They simply follow the alternations of the Yin and Yang and the four seasons. 
The Unborn is by our side yet alone,

The Unchanging goes forth and returns.

Going forth and returning, its successions are endless

By our side and alone, its Way is boundless.

Therefore, that which gives birth to things is unborn, that which changes things is unchanging. Birth and change, shape and color, wisdom and strength, decrease and growth, come about of themselves. It is wrong to say that it brings about birth and change, shape and color, wisdom and strength, decrease and growth(Graham 17-18).

Liezi believed that Tao is the ultimate source or basis of all things in the universe. It is not only a creator and changer of the world, but also something that could not be created or born by anything else in the world. ${ }^{3}$ So, Tao is not one of prescriptive existence and without any limitation of time and space. ${ }^{4} \mathrm{As}$ a generator and transformer, Tao never stopsgenerating and transforming. However, Taois not a humanlike thing witha strong and selfish will. Taonevergenerates or transforms anything in the universe directly and consciously, as theLiezidescribed: "It is wrong to say that it brings about birth and change, shape and color, wisdom and strength, decrease and growth." Taoisthe "fundamental power" of theoperation of the universe, but itseffect on thingsis extremely weak that even cannot mastertheir existence and change. That is to say, the "birth and change, shape and color, wisdom and strength, decrease and growth" of all things are mainly decided and completed by their own nature and internal driving energy, and this is the so-called"autogeneration and self-transformation."

Moreover, the "auto-generation and self-transformation" here refers not only to the process that things do by themselves naturally, ${ }^{5}$ but also to the one that things have to be done, because the process of "auto-generation and self-transformation" is also a reflection of Tao. In this context, people's pursuit of the ultimate meaning of "Tao" should be reflected in the development and improvement of every individual life, in a word, in "tending life." And anything that might impede one's natural development and improvement is a roadblockagainstthe pursuit of Tao.In this sense, the theory of "tending life" also reflects a pursuit that transcends the physical life.Yet the development and improvement of one's life must be based on the preservation of the body, which means that the pursuit of Tao must be based on people's natural physical requirements as well. 


\section{Living Without Restraint:The Best Wayof "Tending Life"}

According to the 'Yangzhu', the body is the keyto understanding and transforming the self (Ronnie Littlejohn \& Jeffrey Dippmann 167). Therefore, the human nature should be the natural desires of the body, which could help tending people's physical lives. Zhang Zhan noted:

It's human nature to enjoy the leisure and avoid the toil. Therefore, the biggest joys in life are nothing but the tasty food, fine clothes, beauties and the music (Yang 108).

The body is the material basis of one's activities and it cannot be replaced by any other person. In this context, the word "self" is an equivalent concept to the "body," and "self- generation" can be also regarded as "to create one's body," just like what Heidegger once said, 'We do not 'have' a body; rather, we 'are' bodily"(Heidegger 99).In 'Yangzhu', the key to tending one's life is not to suppress any natural desire. To support this argument, we couldturn to an interesting story in 'Yangzhu'. Yan Ying 晏嬰 asked GuanZhong管仲about tending life, and GuanZhonganswered that the best way is "living without restraint":

Give yourself up to whatever your ears wish to listen to, your eyes to look on, your nostrils to turn to, your mouth to say, your body to find ease in, your will to achieve. What the ears wish to near is music and song, and if these are denied them, I say that the sense of hearing is restricted. What the eyes wish to see is the beauty of women, and if this is denied them, I say that the sense of sight is restricted. What the nostrils wish to turn to is orchids and spices, and if these are denied them, I say that the sense of smell is restricted. What the mouth wishes to discuss is truth and falsehood, and if this is denied it, I say that the intelligence is restricted. What the body wishes to find ease in is fine clothes and good food, and if these are denied it, I say that its comfort is restricted. What the will wishes to achieve is freedom and leisure, and if it is denied these, I say that man's nature is restricted. All these restrictions are oppressive masters. If you can rid yourself of these oppressive masters, and wait serenely for death, whether you last a day, a month, a year, ten years, it will be what I call "tending life". If you are bound to these oppressive masters and cannot escape their ban, though you were to survive miserably for a hundred years, a thousand, ten thousand, I would not call it "tending life"(Graham 142). 
The saying of "an intact life is best; a diminished life is next; death is lower still; a tormented life is the worst" in LüshiChunqiuis probably the best summary of the argument above. In Guan Zhong's view, the major manifestation of human nature is the desires of the senses, and the best way of "tending life" is "living without restraint" so that all the senses can be smoothly satisfied. Otherwise, if all the senses are suppressed and restricted, one's physical life will become an "oppressive master" because his/her human nature has been totally damaged. Human life is extremely short when compared to the life of the universe, and in this short period of time, there are only a handful of days that are truly complacent and worry-free. In this regard, people can have two choices: one is to extend the length of life as much as possible; the other is to fully satisfy the senses of nature in this limited lifetime. In this story, Guan Zhong obviously chose the latter. In his view, people cannot control their own wealth, nor can they master their own health. Therefore, people do not have to be attached to the length of life. As we can see, the core of "tending life" in this story is not to pursue the immortality of the body so much, but to satisfy the natural desire to the greatest extent in one's limited life.

\section{Attachment to "Ming(名)" : The Obstruction in "Tending Life"}

In 'Yangzhu', human beings are the most intelligent creature in the world because they could live abetter life than any other creatures by their wisdom. Therefore, the value of wisdom is to protect and preserve people's life, which means that the purpose of thinking is not to pursue things beyond the natural demands, but "tending life." However, people often use their wisdom to overflow their own natural limitations, or intend to change their uncontrollable "Ming”命（Fate/Destiny）, such as the longevity, the reputation, the social status and the wealth. So we can find the saying in 'Yangzhu':

A grand house, fine clothes, good food, and beautiful women -- if you have these four, what more do you need from outside yourself? One who has them yet seeks more from outside himself has an insatiable nature. An insatiable nature is a grub eating away one's vital forces"(Graham 156).

Among all those things "outside oneself" ,Liezi specifically criticized theattachment of “Ming”名(Name/Reputation). And also,'Yangzhu' involved the relationship between "Ming" and "Shi"實(Reality)frequently when constructing the theory of "tending life," which reminds us to pay attention to the discussions of "Ming (名)" in the this chapter. 
Some scholars have pointed out that there are two main meanings of "Ming (名)" in ancient Chinese thoughts: One is the "name" of things in the linguistic or logical context, and the other represents the "fame" or "reputation" in the ethics and political sense (Cao, "Backing to the intellectual history," 59-64). Yang Zhu mainly criticized "Ming (名)" from the perspective of ethics and politics, but all these critics were based on the argument of the linguistic and logical meaning of "Ming (名)." Therefore, we could see these two aspects in 'Yangzhu' chapter's discussions of "Ming (名)."

First, from the perspective of linguistics and logic, there is no inevitable correspondence between the name and the reality. 'Yangzhu'noted: "Reality has nothing to do with the name; name has nothing to do with reality. The name is nothing but pretence"(Graham 138).Generally, the concept of "name" is used to refer to the "reality," and the "name" must be corresponded correctly with the real, otherwise the concept "name" is meaningless. However, it is believed in the 'Yangzhu' that those sages who regarded their reputation as their "life" didnot lived a real and happy life, for there was no inevitable correspondence between "name" and "reality" in the real world. The word "Wei(偽)" in this paragraph could have two meanings, one is artificiality, and the other is fakeness. However, both of these actually expressed doubts about the authenticity and validity of “name.”Laozipointed out: “Naming (Ming名) that can assign fixed reference to things is not really naming. The nameless (Wuming無名) is the fetal beginnings of everything that is happening"(Ames, R. T, \& Hall, D. L.).The original state of the world is an unnamed chaos, and that means the truest form of a thing is its reality, but not the name that was given by people. In this context, the universe cannot be named originally, and our method of naming all things is just a way to distinguish and recognize things around us. However, not everyone can recognize the limitation of the "name." Some people can only see the "name" but ignore the "reality" behind. Over time, people get used to regard the "name" as the "reality," and the real "Reality" is obscured. As we know, the thought of Taoism has always advocated that people should soberly recognize the limitations of the "name" and give up their reliance on the certainty of the "name." And it is obvious that the discussion on the relationship between the "name" and the "reality" in the "Yangzhu'also continued the tradition of Taoist thought.

Second, from the perspective of ethics and politics, there is no inevitable connection between reputation and "tending life."In the tradition of Taoist thought, the existence of 
"name" means the appearance of differences, which leads to the birth of orders. In the real life, the differences and orders are manifested as variety of political norms and ethical rules, and a good "name" means a good reputation that meets the requirements of these norms and rules. In other words, in real life, "name" refers to "reputation." Correspondingly, the so-called "reality" in 'Yangzhu' is the actual state of human nature: "It is care and vexation which go against our nature, ease and joy which accord with it. Then a real gain is attached to reputation" (Graham 156). To support this argument, Yang Zhu set those ancient sages as example. Boyi伯夷and Shuqi叔齊, who regarded their reputation of "purity" and "correctness" as their "life," gave up their own physical life only to leave no one to inherit their will. We are also reminded that the famousemperor Yao堯, Shun舜, Yu禹, Tang湯, King Wen文王, King Wu武王, Duke Zhou周公 and Confucius孔子also traded their lives for good reputation in the history, but they all suffered from miserable lives and could not have any joyful time. Therefore, sometimes the reputation which is beyond the natural life cannot preserve people's life, but can damage their body and keep them from enjoying daily life. This is the loss of "reality" in pursuit of "name." Moreover, as the 'Yang Zhu'figured:

It is in life that the myriad things of the world are different; in death they are all the same. In life, there are clever and foolish, noble and vile: these are the differences. In death, there are stench and rot, decay and extinction; in this we are all the same(Graham 140).

In the face of inevitable and general death, how could people's reputation have anything to do with them? And what is the difference between a good reputation and a bad one?

To sum up, the obsession with "name" can obscure the "reality" of the world, just as the excessive desire for fame can lead people to damage themselves and lose the intent of "tending life." It can be said that the original purpose of the generation of the "name" was to approach the "reality," but in the end people was trapped in the "name" world. And also, the gap between the "name" and the "reality" often leadsthe inclination from real to fake. Just like the 'Yangzhu'discussed: "We must never forget that we are living this precious life, waiting for death which comes too soon; and to wish to impress others with your respect for propriety and duty, distorting your natural passions to call up a good name, in our judgment is worse than death"(Graham 145).

\section{Roaming as the Nature Prompt: The Ultimate Purpose of "Tending Life"}


It is worth to notethat there seems to be some unclear association between the human nature and those things beyond it. For example, while criticizing the greed for property, the 'Yangzhu' also showed interest on big houses and beautiful clothes. Maybe someone will criticize that the thoughts in 'Yangzhu' are self-contradict, but in fact, we need to see that the development of the "tending life" theory was based on both the "Ming (命)" and the “auto-generation"theories. In other words, the concepts of "Ming (命)" and human nature can be combined in the 'Yangzhu'. In the 'Liming'力命, “Ming (命)" means the fate of life, wealth and other things that are beyond people's control.Furthermore, "Ming"命also means one's role, identity or even the social order. As the example given by the 'Yangzhu', if an old farmer who is used to a busy life is allowed to enjoy leisure, he may become worriedand upset. In the view of the 'Yangzhu', those "big houses" and "fine clothes" should be acquired without exceeding people's natural requirements. In this context, people have to settle for their own position rather than claiming more wealth and status indefinitely. If a person plays a certain role, he should settle down in his own identity and satisfy his natural desires to the fullest extent within his limitation. And this is exactly what the 'Yangzhu' claimed. At the same time, the 'Yangzhu' strongly opposed all pursuits (such as the reputation) that beyond natural desires or one's own identity.

The argument above is very dialectical, which makes us to re-examine some of the sayings in the 'Yangzhu'. A very typical example is that although 'Yangzhu' denied that "reputation" is a necessary condition for "tending life," it also believed that these two concepts are not mutually exclusive:

Is a reputation really indispensable; is it really impossible to treat it as a passing guest?Now a good reputation brings honor and glory, a bad one humiliation and disgrace.... Then a real gain is attached to reputation. How can we dispense with it, how can we treat it as a passing guest? The one thing we should dislike is getting involved in real difficulties by chirping to reputation. If you involve yourself in real difficulties by clinging to it, you will have irremediable ruin to worry about, not only the choice between ease and care, joy and vexation(Graham 156)!

The 'Yangzhu' clearly pointed out that the honor and glory that the reputation brings to people can also lead people to a comfortable and happy life, and what is repulsive is just the act of merely pursuing fame instead of tending life. Therefore, if the reputation is in a 
state that does not damage the human nature and even can help "tending life," then there is no need to deliberately exclude the reputation at this time.

Another example is the attitude towards wealth. As 'Yangzhu' said:

Yuan Hsien grew poor in Lu, Tzu-kung grew rich in Wei. Yuan Hsien's poverty injured his life, Tzu-kung's wealth involved him in trouble.

If that is so, wealth and poverty are both bad; where is the right course to be found?

It is to be found in enjoying life, in freeing ourselves fromcare. Hence those who are good at enjoying life are not poor, and those who are good at freeing the themselves from care do not get (Graham 141).

In the view of the 'Yangzhu', though the greed of wealth is not worth advocating, people don't need to keep themselves in a state of impoverishment and thus damage their physical life. A person who is good at tending life will definitely use his wealth to satisfy his natural desires. What he should pay attention to is not to shift the protection of life to the pursuit of wealth, and only in this way could he live a life that is totally natural, and of course, is merged with Tao.

Now we can draw a conclusion that the 'Yangzhu' neither promoted that people should restrain their desires, nor advocated indulgence. The main idea of "tending life" is not to suppress any desires, nor to over-indulge. It's all about the human nature and the theory of "tending life." What people should do is to preserve their energy of life, obey the requirements of nature and maintain their physical and mental comfort in the most natural state. And that is the so-called "roaming as the nature prompt."

\section{Conclusion}

Most scholars now incline to summarize the main idea of "tending life" theory in 'Yangzhu' as a sort of "hedonism," “extreme egoism” or "indulgence." However, could these concepts depict the whole picture of the thought of the 'Yangzhu'? The answer may be "No." Although it's still difficult to determine whether the word "Ming (命)" in the 'Yangzhu' refer to one's physical body or the spiritual life, we are more inclined to understand it as a form of the combination of the both, at least we cannot deny the existence of spiritual factors. As aTaoistarticle, the 'Yangzhu' also regarded Tao as the ultimate meaning of people's life. Tao does not dominate people's lives, but assists people to preserveandpromote their lives naturally bythemselves. In addition, the discussion on the 
relationship between the "name" and the "reality" in the "Yangzhu' also reflected the consideration on the ultimate meaning of people's life. Inthissense, the theory of "tending life" in the 'Yangzhu' should not be considered as a promotion of physical enjoyment, and the most ideal life should "roaming as the nature prompt," which is also difficult to realize. As FengYoulan馮友蘭once said:“It must be admitted that it is not easy to do exactly what Yang Zhu said $\cdot \cdots \cdot$ The lifestyle described in the 'Yangzhu' can only be realized by those whoare fairly and really philosophical'(Feng 500).

\section{Notes}

1. Boqian,Jiang蔣伯潛 argued that “the 'Yang Zhu' chapter in the Lie Zi advocated only indulgence. The influence of this tendency was even worse than that of King Jie (桀) and King Zhou (紂). How can this be compared with Yang Zhu's "tending life" theory? This is just the concentrated expression of decadent thoughts during the Wei and Jin dynasties.” See Jiang.ZhuziTongkao諸子通考(Comprehensive Examination of Masters).Shanghai: Shanghai Classics Publishing House, 2013.In addition, Yang Bojun楊伯峻also believed that “(Scholars in the Jin dynasty) concocted a 'Yang Zhu' chapter in the Lie Zi to depict a Yang Zhu in their minds in order to find a theoretical basis for their indulgence.” See Yang,Bojun.Lie ZiJishi列子集釋 (Collected Explanations Of The Liezi) .Beijing: Zhonghua Book Company.2012.

2. Although FengYoulan馮友蘭 considered Liezi to be a pseudograph, he also believed that the spirit of the 'Yang Zhu' chapter is totally different from that of the Wei and Jin dynasties. He said, “(The 'Yang Zhu' chapter) focused on the physical happiness of the person, and the "tending life" theory in it also concentrated on the human body. This is not the spirit of Xuanxue玄學 which mainly focused on the spiritual liberation. See Feng,Youlan馮友蘭,ZhongguoZhexueshiXinbian中國哲學史新編(A New History of Chinese Philosophy).Beijing: People's Publishing House.1998.P.186. The similar argument could be found in Xu's book. See Xu,Kangsheng許抗生.Daojiao Yu XiandaiWenming道教與現代文明(Taoism and Modern Civilization).Beijing: Zhonghua Book Company,2015.P. 90.

3. As the 'Confucius' chapter said: "To be born normally, coming from nowhere, is the Tao."

". As the 'Heaven's Gift' chapter said: "Hence the Way of heaven and earth must be either Yin or Yang, the teaching of the sage must be either kindness or justice and the myriad things, whatever their functions, must be either hard or soft. All these observe their functions and cannot leave their places."

${ }^{5}$. Tomohisa Ikeda figured that "The ancient meaning of the word "natural" in Chinese is 'I' or 'self', which means not to move without relying on any external force but on one's own internal energy. This connotation is consistent with the characteristic of the 'autogeneration and self-transformation' theory here." (YūzōMizoguchi\&Kojima Tsuyoshi[ed].Zhongguo de SiweiShijie中國的思維世界（The World of Thought in 
China) .Trans.Ge Sun, etc. Nanjing: People's Publishing House of Nanjing.2006.P.16.) Besides, LihuaYang楊立華 once noticed the difference between “I”(我) and "Self" (自). He believes that "I" emphasizes the subjectivity of the individual, while "Self" refers to the limits of one's knowledge and ability. In this sense, "auto-generation and self-transformation" can be interpreted as the process that is beyond one's limits. See Lihua,Yang.Guo Xiang ZhungzizhuYanjiu郭象《莊子註》研究 (A study of Guoxiang's Annotations on Zhuangzi) .Beijing: Peking University Publishing House.2010. P. 105.

6. Our Master Huazi said: An intact life is best; a diminished life is next; death is lower still; a tormented life is the worst. Accordingly, what is called an "honored life" refers to an intact life. In an "intact life" each of the six desires obtains what is proper to it. In a "diminished life" only half of the six desires attain satisfaction. When life is so diminished, its value is lessened. The more life is diminished, the less it is valued. What is called "death" consists in the lack of any capacity for aware ness, and a return to the state before birth. In a "tormented life" none of the six desires obtains its proper satisfaction; rather, each desire obtains only what it has a natural aversion to. Servitude and disgrace are instances of this. No disgrace is greater than that of being treated contrary to your code of conduct. Thus, to lead a tormented life means being treated immorally. But a tormented life does not consist merely in being treated immorally therefore, it is said that a tormented life is worse than death. (LüshiChunqiu,KnoblockJ. \&RiegelJ. P.83)

\section{Works Cited}

Ames, R. T, \& Hall, D. L. Daodejing_ “Making This Life Significant”: A Philosophical Translation. New York: Balantine Books.2003

Cao,Feng曹峰.“Backing To The Intellectual History : New ways to The Studies Of Ming in Pre-Qin." Shandong DaxueXuebao, no.2, 2007, pp.59-64.

Cao,Feng曹峰. “Development and Evolution of the Concept of Auto-Generation: Taking

Hengxian as an Example."ZhongguoZhexueshi, no.2, 2016, pp.18-26.

Feng,Youlan馮友蘭. 中國哲學史新編(A New History of Chinese Philosophy).Beijing:

People's Publishing House, 1998 .

Graham, A. C. The Book of LiehTzu . New York: Columbia University Press. 1990. $\mathrm{Hu}$,Shih胡適.中國哲學史大綱(An Outline History of Chinese

Philosophy).Beijing:Zhonghua Book Company.2015.

Jiang, Boqian蔣伯潛.諸子通考(Comprehensive Examination of Masters).Shanghai:

Shanghai Classics Publishing House.2013.

Knoblock J. \&Riegel J.The Annals of LüBuwei. Stanford: Stanford university press. 2000. Liu,Zongyuan柳宗元.柳河東集(The Collected Writings of Liu Hedong). Shanghai:

Shanghai Classics Publishing House.2008.

Martin Heidegger.Nietzche(Vol.I\& II). Trans.David Farrell Krell.NewYork:Harper Collins Publishers.1991.

Mencius孟子.Mencius. Trans. Irene Bloom.New York: Columbia University Press. 2009.

Qian,Mu錢穆. 先秦諸子繫年(An Annalistic History of the Pre-Qin Masters). Beijing: The

Commercial Press.1998.

Watson, B. ZhuangZi: basic writings. New York: Columbia University Press.1964. 
Xu,Dishan許地山.道教史(A History of Taoism).Shanghai: Shanghai Classics Publishing House, 2011.

$\mathrm{Xu}$, Kangsheng許抗生.道教與現代文明(Taoism and Modern Civilization).Beijing:

Zhonghua Book Company.2015.

Yang,Bojun楊伯峻.列子集釋(Collected Explanations Of The Liezi).Beijing: Zhonghua Book Company.2012.

Yang, Lihua楊立華. 郭象《莊子註》研究(A study of Guoxiang's Annotations on Zhuangzi).Beijing: Peking University Publishing House.2010.

YūzōMizoguchi\&Kojima Tsuyoshi ed.中國的思維世界(The World of Thought in China).Trans.Sun Ge, etc. Nanjing: People's Publishing House of Nanjing.2006. 